\title{
From Crime Control Model to Due Process Model: A Critical Study of Wiretapping Arrangement by the Corruption Eradication Commission of Indonesia
}

\author{
Hwian Christianto* \\ DOI: https://doi.org/10.22304/pjih.v7n3.a7
}

Submitted: September 29, 2020 | Accepted: October 31, 2020

\begin{abstract}
This study compares three formal criminal laws on the corruption act to show the importance of due process model for wiretapping/lawful interception in Indonesia. Investigators of Indonesian Corruption Eradication Commission (KPK) assume that the implementation of wiretapping based on the due process model decelerate the performance and independence of corruption eradication. The problem particularly happens on the execution of caught in the act operation. This study covers the design of wiretapping on corruption case linked with the due process model as an effort to guarantee the right of privacy. Firstly, legislators accentuated an effective corruption eradication, which highlights the implementation of the crime control model. Secondly, the latest amendment to the Law on Corruption Eradication Commission of Indonesia alters wiretapping to become a procedural activity for stronger synergy among the law enforcement institutions. The regulation of wiretapping as a method to reveal corruption case in Indonesia does not adhere to the due process model entirely. The wiretapping still tends to deal with stages of preliminary-investigation, investigation, prosecution, and the execution of internal approval process.
\end{abstract}

Keywords: corruption, crime control model, due process model.

\section{From Crime Control Model to Due Process Model: Studi Kritis Pengaturan Penyadapan oleh Komisi Tindak Pidana Korupsi Republik Indonesia}

\begin{abstract}
Abstrak
Hasil penelitian atas tiga undang-undang hukum pidana formil terkait tindak pidana korupsi di Indonesia menunjukkan pentingnya model due process dalam penyadapan. Penyidik Komisi Pemberantasan Korupsi Republik Indonesia memandang pelaksanaan penyadapan berdasarkan model due process memperlambat kinerja dan independensi penegakan korupsi terutama dilakukannya Operasi Tangkap Tangan. Artikel ini membahas rancang bangun penyadapan pada tindak pidana korupsi dikaitkan dengan model due process sebagai upaya menjamin hak asasi manusia, secara khusus hak privasi. Pertama, awalnya pembentuk undang-undang lebih menekankan pemberantasan tindak pidana korupsi secara efektif sehingga menunjukkan penerapan model pengawasan tindak pidana. Kedua, UU KPK RI mengubah penyadapan lebih prosedural dengan harapan menguatkan sinergitas
\end{abstract}

PADJADJARAN Journal of Law Volume 7 Number 3 Year 2020 [ISSN 2460-1543] [e-ISSN 2442-9325]

Lecturer of Criminal Law, at Faculty of Law, University of Surabaya, Jalan Raya Kalirungkut Surabaya, S.H. (Universitas Airlangga), M.H. (Universitas Airlangga), Dr. (Universitas Gadjah Mada), hw_christianto@staff.ubaya.ac.id 
antar lembaga penegak hukum. Pengaturan penyadapan atas tindak pidana korupsi di Indonesia masih belum sepenuhnya memberlakukan model due process. Penyadapan masih bersifat sektoral dengan mencakup tahap penyelidikan, penyidikan dan penuntutan serta menjalankan proses perijinan secara internal.

Kata kunci: korupsi, model due process, model pengawasan tindak pidana.

\section{A. Introduction}

In 2019, the Corruption Perception Index for Indonesia has experienced positive changes. It scored 40 of 100, ranked 85 of 180 states. ${ }^{1}$ This record shows progress from 2018. Previously, Indonesia got 38 and ranked $89 .^{2}$ This achievement is certainly inseparable from the efforts of law enforcement mechanisms. One of the efforts in 2019 includes wiretapping. The characteristics of corruption as a complex organized crime require wiretapping as a strategic and fast step to gather evidence from suspected corruption cases. The importance of wiretapping is emphasized as

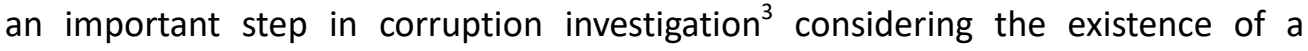
Comprehensive Long Term National Strategy on Corruption Prevention and Eradication 2012-2025 and the Mid-Term 2012-2014 (Nastra CPE). ${ }^{4}$ However, there are still pros and cons from the public on wiretapping as a strategic step to tackle corruption. There are several factors, including differences in community perceptions, ${ }^{5}$ culture and community conditions, ${ }^{6}$ political situations or community system, ${ }^{7}$ the influence of high public-administration cost, social conflict, public distrust of the government, ${ }^{8}$ and citizens' subjective reasons. ${ }^{9}$

1 Transparency International, "Corruption Perceptions Index", https://www.transparency.org/cpi2019, accessed on April 2020.

2 Ibid.

$3 \quad$ Jure Rus, "Effective Detection and Investigation of Corruption", Proceeding Expert Seminar Effective Means of Investigation and Prosecution of Corruption: OECD Anti-Corruption Network for Eastern Europe and Central Asia, Bucharest-Romania, October 20-22, 2010, p. 23.

4 Indonesia commits to support the corruption eradication mechanism through "a) to build and establish an integrated system, mechanism, capacity to prevent and take action against corruption on a national scale" (bottom line from HC). See United Nations Office on Drugs and Crime, National Strategy Corruption Prevention and Eradication of Republic of Indonesia", https://www.unodc.org/documents/indonesia/publication/2012/Attachment_to_Perpres_55-

2012_National_Strategy_Corruption_Prevention_and_Eradication_translation_by_UNODC.pdf, accessed on May 2020.

5 B.A. Olken, "Corruption Perceptions vs. Corruption Reality", Journal of Public Economics, Vol. 93, No. 7, 2009, pp. 950-964.

$6 \quad$ R.A. Bernardi \& I. Hayashi, "The Association between Bribery and Unethical Actions: An Asian Perspective", European Journal of Business and Innovation Research, Vol. 1, No. 2, 2013, pp. 70-84.

7 Vicente H. Monteverde, "Microeconomics of Corruption Based on Behavioural Economics", Journal of Financial Crime, 2020, p. 3, https://www.emerald.com/insight/content/doi/10.1108/JFC-03-20200043/full/html?skipTracking=true.

$8 \quad$ Yooung Jong Kim, \& Eun Sil Kim, “Exploring the Interrelationship Between Public Service Motivation and Corruption Theories", Evidence-Based HRM, Vol. 4, No. 2, 2016, pp. 181-186.

9 Beverlee B. Anderson, "Corrupting Activities and Economic Development", World Journal of Entrepreneurship, Management and Sustainable Development, Vol. 11, No. 1, 2015, pp. 64-70. 
The development of wiretapping arrangements for suspected corruption has also undergone changes in line with a new law, the Law number 19 of 2019 on the Second Amendment to the Law Number 30 of 2002 on the Corruption Eradication Commission of the Republic of Indonesia. The amended KPK Law specifically regulates wiretapping in detail and different from the previous arrangement. The arrangement has created a debate regarding the effectiveness of wiretapping regulations in relation to the characteristics of corruption. The pros emphasize the superiority of the clarity of wiretapping procedures for the fulfillment of human rights, particularly the right to privacy. Contrary to this opinion, the cons consider the KPK Law reducing the independence and the effectiveness of handling corruption cases.

Further discussion is emphasized on wiretapping as a law enforcement process in relation to the appropriate law enforcement model. The first discussion describes the characteristics of wiretapping to handle corruption based on the valid law and regulations and to be a design for law enforcement on corruption cases. The next discussion is emphasized on the law enforcement model applied in corruption cases as a due process model or crime control model equipped with a comparative study on relevant regulations.

The study used a normative juridical research method focused on regulations related to corruption, the KPK, and wiretapping. The initial part emphasizes that the policy to regulate corruption is linked to the wiretapping of the KPK Law starting from the Law number 20 of 2002 in conjunction with the Law number 10 of 2015 and the Law number 19 of 2019. The regulatory model for wiretapping serves as the foundation to understand the law enforcement model, the crime control model, or the due process model.

\section{B. Characteristics, Design, and Construction of Wiretapping in Corruption Case and Comparison of Arrangement}

\section{Characteristics of Wiretapping in Law Enforcement of Corruption Crimes}

Garner explains two interchangeable terms "interception", which means "to cover, receive, or listen to (a communication), and "wiretapping", which means electronic or mechanical eavesdropping, usually done by law-enforcement officers under court order, to listen to private conversations. ${ }^{10}$ This manuscript uses both terms interchangeably. The first term refers to the act of taking or receiving communications; while the second term refers to the means used to retrieve or receive confidential communications by law enforcement agencies. The understanding of wiretapping in the KPK Law has the same understanding as the term "intercept". Article 1 paragraph 5 of the Second Amendment to the KPK Law confirms the nature of interception. ${ }^{11}$ Based on this definition, there are three main

Bryan A. Garner, Black's Law Dictionary, Eighth Edition, New York: West-Thomson, 2004, p. 1142.

Article 1 point 5 of the Second Amendment of the KPK Law defines "wiretapping" (Indonesian: Penyadapan) as an activity to listen to, to record, and / or to tap the transmission of electronic information and / or 
points of interception. The first covers interception as an activity or a series of activities of a law enforcement agency in a certain stage of preliminary-investigation or investigation. The second is the method of intercept conversation, message, information, and/or communication network. The third is object of the interception in telephone line and/or other electronic communication tools. The new thing lies in the second thing covering the method of intercepting conversations, messages, information, and/or communication networks. The KPK Law does not explicitly regulate the method and the object of interception. It is possible that interception is practiced with or without knowledge of the communicating parties. The final understanding differs from the definition of "wiretapping", which emphasizes the legal procedure for tapping as a 'court order'. However, it does not mean that even though the KPK Law does not emphasize wiretapping as a legal procedure or not, wiretapping is carried out for the purpose of preliminary-investigation or investigation. The reason for the sake of law is the basis for law enforcers to intercept, including the police. ${ }^{12}$

The KPK Law does not explain in detail about preliminary-investigation or investigation of corruption crime. Further understanding must refer to the Law Number 8 of 1981 on the Criminal Procedure Law. Investigation efforts aims to find and to reveal suspected criminal acts (Article 1 point 5) through receiving reports or complaints of criminal acts, seeking information and evidence, ordering suspect to stop, and examining personal identification, making arrest, investigating/confiscating letters, taking fingerprints, and confronting an investigator. $^{13}$ It is in contrast to investigations to find and to collect evidence of criminal acts and suspects. ${ }^{14}$ The two definitions may lead to various understanding of the purpose of wiretapping. Tapping in a preliminary investigation is intended to determine whether a 'suspected criminal act' is really a crime act. It is different from tapping in the investigation stage, which look for evidence to convict a criminal act and the perpetrator. Although law enforcement enables tapping in the two stages of the legal process, preliminary investigation raises specific problems. It is important to understand that a preliminary investigation is the stage of making clear that an act is a criminal act or not. There is a possibility that a suspected act is not a corruption. Tapping at the preliminary-investigation stage is also detrimental to a suspect of a criminal act. It disrupts human rights to security and privacy. ${ }^{15}$

electronic documents that are not public in nature, whether using communication cable networks, wireless networks, such as transmissions. electromagnetic or radio frequency or other electronic devices". The Law Number 19 of 2019 on Second Amendment to the Law Number 30 of 2002 on the Corruption Eradication Commission.

12 Armunanto Hutahean \& Erlyn Indarti, "Implementation of Investigation by the Indonesian National Police in Eradicating Corruption Crime", Journal of Money Laundering Control, Vol. 23, No. 1, 2020, p. 151. See further S. Faisal, Menerobos Positivisme Hukum, Kritik terhadap Peradilan Asrori, Bekasi: Gramata Publishing, 2012.

Article 5 of the Criminal Procedure Law.

Article 1 paragraph 2 of the Criminal Procedure Law.

The legal basis for protecting the right to privacy as a constitutional right is in Article 28G paragraph (1) of the 1945 Constitution of the Republic of Indonesia, which states "Everyone has the right to protection of 
In relation to law enforcement efforts in a case of suspected corruption, Setya Novanto, the former Speaker of the Indonesian House of Representatives once requested a constitutional judicial review on the implementation of Article 46 paragraph (1) of the KPK Law against himself as a Government Official. The judicial review aimed to make the preliminary-investigation and investigation requiring approval from the President of the Republic of Indonesia. ${ }^{16}$ The nine judges of the Constitutional Court of the Republic of Indonesia unanimously made the Decree Number 95/PUU-XV/2017 to mention that Article 46 paragraph (1) of the KPK Law remains constitutional. The implementation of Article 224 paragraph (5) of the Law Number 17 of 2014 is disregarded by taking into account Article 245 paragraph (1) of the Law Number 17 of 2014. Written approval from the President of the Republic of Indonesia is not needed in the investigation of a government official under several conditions. They are, among others, (a) caught in the act of committing a crime, (b) suspected of having committed a crime punishable by death or life imprisonment or a crime against humanity and state security based on sufficient preliminary evidence, or (c) suspected of committing a special crime. Point (c) seems to be the foundation of strong consideration to conduct preliminaryinvestigation and investigation on government officials without the approval of the President, particularly in corruption cases. Specific understanding of corruption as a special crime can be interpreted from the Concern Section of the Corruption Eradication Law, the Law Number 31 of 1999 in conjunction with the Law Number 20 of 2001. Corruption is very detrimental to state finances and the national economy, hindering national development, which demands high efficiency as well as a law regulating corruption to replace the Law Number 3 of $1971 .{ }^{17}$ Therefore, wiretapping is allowed at investigation stage to enforce the law on corruption as a special crime.

\section{Design of Wiretapping in Corruption Case}

The history of wiretapping design in corruption case needs to be understood juridically based on all provisions regulating wiretapping. Before the implementation of the Criminal Code, the Law Number 11 of 1963 on the Eradication of Subversion Activities gave investigators enormous powers, including

themselves, personal, family, honor, dignity and property under their control and the right to feel safe and protection from the threat of fear to do or not do something, which is a human right".

16 Setya Novanto questioned the constitutionality of Article 46 paragraph (1) of the KPK Law, which is not automatically applied to him as a government official as regulated in Article 224 paragraph (5) of the Law Number 17 of 2004 on the People's Consultative Assembly, the People's Representative Council, the Regional Representative Council, and the Regional People's Representative Council.

17 The Law number 31 of 1999 on Eradication of Corruption in conjunction with the Law Number 20 of 2001 on the Amendments to the Law Number 31 of 1999, the General Elucidation section, also mention corruption as a special crime, which has a sophisticated and complex modus operandi of irregularities in state finances that is detrimental to state finances. 
wiretapping, although it was not explicitly stated. ${ }^{18}$ The Criminal Code does not regulate wiretapping explicitly. One of the powers of investigators according to Article 5 letter a point 2 of the Criminal Procedure Code reads "to seek information and evidence" while the authority of investigators according to Article 7 paragraph (1) letter j reads "to take other actions according to responsible law". Based on the two provisions, both preliminary investigator and investigator have enormous authority even no clear boundaries. The inexistence of explicit regulation on wiretapping does not automatically make it permitted.

Wiretapping arrangement was initially introduced in the Law Number 5 of 1997 on Psychotropics (Psychotropic Law) and the Law Number 22 of 1997 on Narcotics (1997 Narcotics Law) and the Law number 35 of 2009 on Narcotics (2009 Narcotics Law). It is considered one of special investigative measures. ${ }^{19}$ There is a certain mechanism for wiretapping according to Article 55 letter c of the Psychotropic Law and Article 66 paragraph (2) and (3) of the 1997 Narcotics Law, in terms of the requirements for wiretapping and the time frame for wiretapping. Based on the two provisions, wiretapping can be performed following strong allegation of psychotropic/narcotics crimes. The maximum period for tapping is thirty days and it cannot be extended. Substantively, in relation with the Criminal Code, wiretapping is a part of an investigator's efforts to obtain evidence of a criminal act, such as in the search and seizure of goods or letters, especially in urgent situations (Article 34 paragraph [2], Article 38 paragraph [2] and Article 43 of the Criminal Procedure Code).

Wiretapping is regulated in more detail in Article 40 of the Telecommunication Law. The Explanatory Section of Article 40 of the Law affirms that wiretapping is an activity of installing additional tools or equipment on a telecommunications network to obtain information illegally. Wiretapping is a prohibited act because it violates the protection of personal rights. The Minister of Communication and Information Technology provides an exception in the case of wiretapping for law enforcement by issuing the Regulation of the Minister of Communication and Information Technology Number 11/PER/M.KOMINFO/02/2006 on the Technical Tapping of Information. Article 9 of the Regulation confirms that the legal retrieval of wiretapping data and information by law enforcers is in accordance with Standard Operating Procedures (SOP). Based on the development, it appears that each law provides different regulations. However, there is still no specific legal provision that regulates wiretapping for all criminal acts, especially in the form of a law. $^{20}$

\footnotetext{
18 Hwian Christianto, "Tindakan Penyadapan Ditinjau dari Perspektif Hukum Pidana”, Jurnal Hukum Prioris, Vol.5, No.2, 2016, pp. 97-98. Ibid.

20 The Decree of the Constitutional Court of the Republic of Indonesia number 5/PUU-VIII/2010 is a decision that accepts a request for a judicial review of Article 31 paragraph (2) of the Law on Information and Electronic Transactions, which stipulates the procedure for wiretapping is further regulated by a Government Regulation.
} 
There is no law that specifically regulates wiretapping. Wiretapping by the KPK is thus based on relevant legal provisions, such as the Criminal Procedure Code and the Regulation of the Minister of Communication and Information Technology number 11/PER/M.KOMINFO/02/2006. This Regulation provides a mechanism for wiretapping, from the pre-wiretapping stage to post-wiretapping, especially using social media as a "new reality". ${ }^{21}$ It is important to understand that the 2006 Ministerial Regulation does not specify the procedure of wiretapping approval. It covers only the mechanism for wiretapping. The permission to do wiretapping is sectoral based on statutory regulations and the authorities of the relevant law enforcement agencies. The KPK does have the authority to carry out wiretapping in accordance with Article 12 of the KPK Law, based on the KPK's internal mechanism. This is necessary considering that corruption involves public officials with the power available to them, giving compensation or economic benefits ${ }^{22}$ will be more difficult to do. The regulation of wiretapping is also centered on the KPK leadership, including in wiretapping permits. ${ }^{23}$ Muqqodas ${ }^{24}$ explains that the KPK in carrying out wiretapping still maintains independence according to its commitment to the KPK's Code of Ethics. As a provision, the KPK's Code of Ethics number 07 of 2013 on Personal Basic Values, Code of Ethics, and Code of Conduct emphasizes Five Personal Basic Values, namely Religiosity, Integrity, Justice, Professionalism, and Leadership. This code of conduct also binds KPK officers internally in carrying out their duties. The KPK's Annual Report also demonstrates the commitment to implementing the code of ethics by conducting Internal Supervision through Audit/Performance Review with Specific Purposes of Wiretapping and Surveillance Activities in $1995 .^{25}$

In addition, the regulation of wiretapping has also developed following the issuance of the Constitutional Court Decree Number 5/PUU-VIII/2010 dated February 24, 2011. It interprets Article 34 paragraph (1) of the Law on Information and Electronic Transactions that wiretapping must be regulated in Law. The Panel of Justices at the Constitutional Court emphasizes the nature of wiretapping as an effort reducing human rights so that it needs to be regulated in specific legal product, a law. This means that the process of wiretapping, from the permit to

21 Edward Howlett Spence, "The Sixth Estate: Tech Media Corruption in the Age of Information", Journal of Information, Communication and Ethics in Society, Vol. 18, No. 4, 2020, p. 2.

22 Hendi Yogi Prabowo \& K. Cooper, "Re-understanding Corruption in the Indonesian Public Sector through Three Behavioral Lenses", Journal of Financial Crime, Vol. 23, No. 4, 2016, p. 1054.

23 Edmon Makarim, "Indonesia: the Controversy Over the Bill Concernining Lawful Interception", Digital Evidence and Electronic Signature Law Review, Vol. 8, No. 1, 2011, p. 131.

24 Endah Lismartini \& Cahyo Edi, ed., "Busyro: Izin Penyadapan Masuk dalam Upaya Pelemahaman KPK", https://www.vivanews.com/berita/nasional/5821-busyro-izin-penyadapan-masuk-dalam-upaya-pelemahankpk?medium=autonext, accessed on May, 2020.

25 Tim Penyusun Laporan Tahunan KPK 2016, “Hingga ke Bawah Permukaan: Laporan Tahun 2016 Komisi Pemberantasan Tindak Korupsi Republik Indonesia", https://www.kpk.go.id/images/Laporan\%20Tahunan\%20KPK\%202016\%20Bahasa\%20Indonesia.pdf, accessed on May 2020. 
mechanism, must be regulated specifically in a Law. The decision of the Constitutional Court of the Republic of Indonesia has important implications in relation with the wiretapping regulations as shown in Figure 1.

Figure 1. Development of Wiretapping Arrangements by the KPK before the Second Amendment of the KPK Law

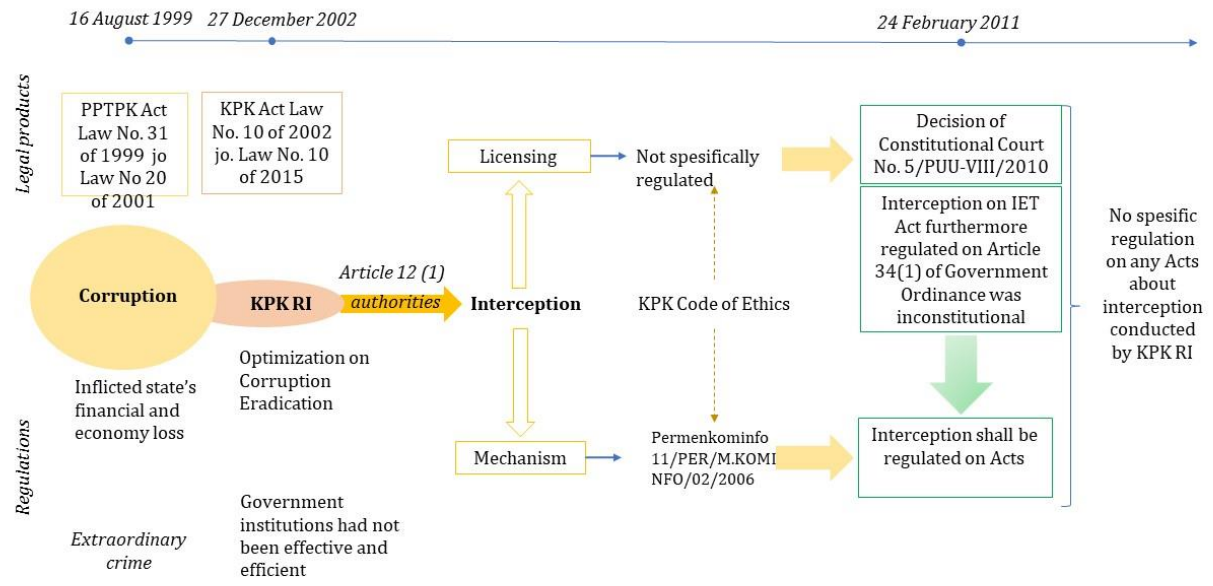

Based on this chart, the Law number 30 of 2002 in conjunction with the Law number 10 of 2015 (the previous KPK Law) has not provided detailed regulations of wiretapping. Wiretapping permits and mechanisms are interpreted based on the KPK's understanding. The previous KPK Law seems to prioritize accelerating the eradication of corruption rather than seeking legal provisions governing wiretapping. This form of legal provision shows the characteristics of the crime control model that prioritizes speed and prosecution of criminal acts ${ }^{26}$ or imposing sanctions on the perpetrators. ${ }^{27}$ Crime Control Model is like a loose boundary ("an assembly line" or "conveyor belt") ${ }^{28}$ emphasizing the principle of the presumption of guil ${ }^{29}$. The results of the prosecution for criminal acts of corruption also show that wiretapping has an important contribution. Evidence from the application of the crime control model can be seen from the data on 21 corruption cases that have been successfully proceeded with the legal process starting from the

26 Herbert L. Packer, The Limits of Criminal Sanction, Standford: Standford University Press, 1968, pp. $150-152$.

27 Vanessa A. Edkins \& Kenneth D. Royal, "Evaluating the Due Process and Crime Control Perspectives Using Rasch Measurement Analysis", Journal of Multidisciplinary Evaluation, Vol. 7, No. 16, 2011, p. 50.

28 Roger B. Dworkin, "The Limits of the Criminal Sanction, by Herbert L. Packer", Indiana Law Journal, Vol. 44, No. 3, 1969, p. 496.

29 Eddy O.S. Hiariej, Hukum Pembuktian, Jakarta: Erlangga, 2012, pp. 30-34. 
wiretapping mechanism. This clearly shows the distinctive features of the crime control model applied in the previous KPK Law. ${ }^{30}$

Changes to wiretapping arrangements are included in the Second Amendment to the KPK Law. The Second Amendment actually provides specific arrangements for wiretapping related to the procedure and purpose of wiretapping. Wiretapping is defined as,

"activities to listen to, to record, and/or to tap the transmission of electronic information and/or electronic documents that are not public in nature, whether using cable networks, communications, wireless networks, such as electromagnetic or radio frequency emission or other electronic equipment."

It emphasizes the understanding of wiretapping as "activities to listen to, to record, and/or to tap the transmission of electronic information and/or electronic documents that are not public in nature". Tapping is not limited to recording but also covers listening and/or tapping or a combination of the three. Information as an object of wiretapping is not public, that is private information. This is related to the protection of the right to privacy as affirmed by Article $28 \mathrm{G}$ paragraph (1) of the 1945 Constitution.

The second amendment of the Corruption Eradication Commission Law regulates this by three important things. Firstly, wiretapping by the KPK is the exercise of the authority to investigate, examine, and prosecute Corruption (Article 12 in conjunction with Article 6 letter e). Wiretapping has been confirmed as the KPK's lawful interception at three stages of the legal process for the eradication of the Corruption. This means that tapping is still recognized as a special effort in law enforcement at three stages of the legal process. Previously, the KPK carried out wiretapping as an effort to investigate criminal acts of corruption as crimes against the state economy, which have an impact on state losses as well as the title of extraordinary crimes and including illegal activities in a broad sense. ${ }^{31}$ Dion emphasizes that the disgraceful and dangerous nature of this criminal act of corruption from a philosophical point of view fulfills five levels of understanding: corruption of principles, moral behavior, people, organizations, and states. ${ }^{32}$ Therefore, corruption needs to be handled specifically with a special mechanism, including wiretapping. The focus of the KPK Law emphasizes on the acceleration of the eradication of corruption, rather than fulfilling the mechanism for carrying out the eradication of corruption. Wiretapping also received full support in its implementation as an effort to eradicate criminal acts of corruption.

Hwian Christianto, op.cit.

Petter Gottschalk, "Categories of Finansial Crime", Journal of Financial Crime, Vol. 17, No. 4, 2010, p. 443.

Michel Dion, "What is Corruption Corrupting? A Philosophical Viewpoint", Journal of Money Laundering

Control, Vol. 13, No. 1, 2010, p. 47. 
Secondly, the KPK has obtained wiretapping permits through a tiered mechanism. The Second Amendment of the KPK Law actually revises the eradication of this criminal act of corruption as an effort to synergize law enforcers related to criminal acts of corruption, including the Police, the Attorney General's Office, and the KPK. Part one of the Consideration of the Second Amendment to the Corruption Eradication Commission Law emphasizes the main principles in the implementation of the eradication of corruption based on "the principle of equal authority and protection of human rights". The importance of wiretapping has changed to no longer focus on directly fighting criminal acts. Wiretapping is an effort to eradicate corruption based on coordination and is carried out without violating human rights. Article 12 of the Second Amendment of the KPK Law regulates that the Leaders of the KPK must submit a written request to the Supervisory Board for wiretapping at both the preliminary-investigation and investigation stages. At first glance, wiretapping permits are very easy but if we understand it from the point of view of handling suspected corruption cases, the internal mechanisms of the KPK are still time-consuming. In normative juridical terms, applications for wiretapping are submitted to the KPK leaders by the task force. The approval of the KPK leaders is not sufficient to proceed with the submission of a request letter to the KPK Supervisory Board. The leaders of the KPK and the task force must conduct a case title before the KPK Supervisory Board (Elucidation of Article 12B). The Supervisory Board will also consider the wiretapping request letter. ${ }^{33}$ Indeed, juridically and normatively Article $12 \mathrm{~B}$ of the KPK Law on the second amendment emphasizes the time limit for issuing wiretapping permit for $1 \times 24$ hours, handling cases of suspected corruption are technical-administrative in nature. Wiretapping is subject to detailed regulation in terms of the licensing mechanism internally.

Thirdly, there is mechanism for limited wiretapping to the obligation of periodic reports and the final accountability report. The Second Amendment of the Corruption Eradication Commission Law does not yet regulate the technicalities for wiretapping so that the KPK task force can refer to the wiretapping provisions in the 2006 Regulation of the Minister of Communication and Information and the KPK Code of Ethics.

Hwian Christianto, "Penyadapan, OTT dan Due Process of Law", https://www.jawapos.com/opini/18/10/2019/penyadapan-ott-dan-due-process-of-law/, accessed on May 2020 
From Crime Control Model to Due Process Model: A Critical Study of Wiretapping Arrangement by the Corruption Eradication Commission of Indonesia

Figure 2. Development of Wiretapping Arrangements by the KPK after the Second Amendment of the KPK Law

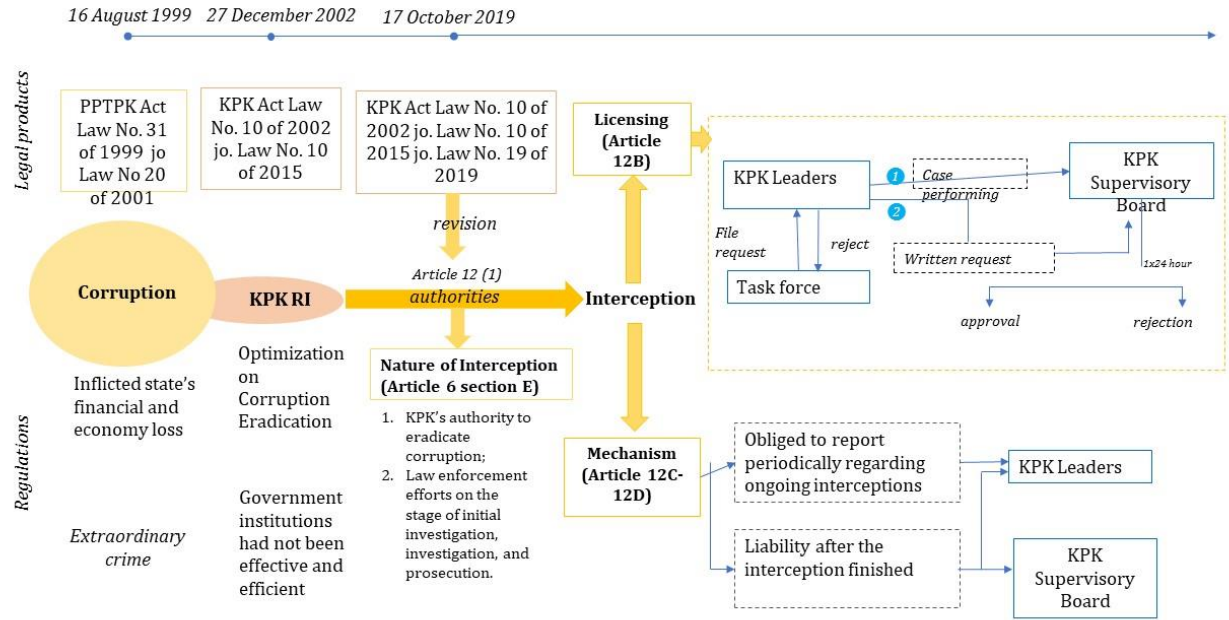

The Second Amendment of the KPK Law provides specific changes in obtaining wiretapping permits and the mechanism for wiretapping. As emphasized by the Amendment of the Corruption Eradication Commission Law in the Consideration Section that the performance of the KPK needs to consider the synergy between law enforcement agencies and the protection of human rights. This means that the eradication of corruption is carried out by taking into account coordination of institutions and the fulfillment of human rights. This is in line with the characteristic due process of law, which emphasizes the number of legal processes or procedures as expected in the trial process. ${ }^{34}$ Hiariej ${ }^{35}$ confirms the due process of law if it is linked to a formalistic evidentiary process that is closely related to the methods to obtain, to collect, and to submit evidence to court. Due process depends on hierarchy and personal quality ${ }^{36}$ of the law enforcement. This can be seen in the process of obtaining a wiretapping permit as emphasized in the Second Amendment of the KPK Law even though the KPK Supervisory Board of the Republic of Indonesia carried it out. Despite the fact that there is the Supervisory Board of the KPK in the process wiretapping permits, the RI KPK still carry it out internally. This means that the consideration and approval of wiretapping permits only extends the permit application flow. On the other hand, the due process model also emphasizes the guarantee and protection of human rights based on the values of

Herbert L. Packer, op.cit., p. 163.

Eddy OS Hiariej, op.cit.

Vanessa Edkins, op.cit., pp. 58-62. 
freedom and autonomy. ${ }^{37}$ This last point also appears to have been affirmed from the start as the main consideration of the Second Amendment of the KPK Law in the Advisory Section, which emphasizes "the principle of equal authority and protection of human rights". The implementation of the law enforcement process must be based on coordination and protection of human rights as the main thing in accordance with the distinctive features of the due process model which prioritizes formalistic legal processes.

\section{Wiretapping Arrangements in the United States and Australia}

Other states have also implemented wiretapping arrangements. As a comparison to Indonesia, the section briefly discusses wiretapping arrangements in states implementing the due process model, the United States and Australia. The selection of the two states was based on consideration of the two countries applying the due process model in criminal cases. This is in line with the Second Amendment of the KPK Law, which implements a due process model in the implementation of wiretapping of corruption cases.

The regulation of wiretapping in the United States was initially understood as an attempt by the government to tackle groups deemed dangerous to society. ${ }^{38}$ The following developments emerged from the case of Olmstead v. United States June 4, $1928^{39}$ related to Olmstead's action. It is prohibited because it took information without consent. Based on the judge's consideration, the wiretapping of Olmstead was deemed to have violated the Fourth Amendment of the United States Constitution. The Fourth Amendment of the US United States Constitution emphasizes the guarantee of security protection for ownership.

"The right of the people to be secure in their persons, houses, papers, and effects, against unreasonable searches and seizures, shall not be violated, and no Warrants shall no..."

It appears that the Fourth Amendment emphasizes on the recognition and guarantee of a person's security rights limited to ownership only. This view changes in the case of Katz v. United States on December 18, $1967 . .^{41}$ Judge Potter Stewart emphasizes an important point that "the Fourth Amendment protects people, not places." It becomes the rationale to implement the due process model to prioritize

37 Elizabeth H. Kaylor, “Crime Control, Due Process, \& Evidentiary Exclusion: When Exceptions Becoma the Rule", Proceeding of the 71st New York State Communication Association, 2014, p. 3.

38 Wiretapping by the United States government raises an ethical dilemma because it is carried out not only in the public but also in private sectors. See Arwen Mulikin \& Shawon SM Rahman, "The Ethical Dilemma of the USA Government Wiretapping", International Journal of Managing Information Technology (IJMIT), Vol. 2, 2010, p. 33.

39 OYEZ, "Case 277 US 438 (1928)", https://www.oyez.org/cases/1900-1940/277us438277US438, accessed on May 2020.

40 United Congress, "Constitution of United States", https://constitution.congress.gov/constitution/amendment-4/, accessed on May 2020.

41 OYEZ, “Case 389 US 347 (1967)”, https://www.oyez.org/cases/1967/35, accessed on May 2020. 
protection and recognition of one's right to security. The application of due process of law is reinforced by the doctrine of reasonable expectation of privacy. Wiretapping must be performed with a court order. Therefore, before lawful interception is carried out, there must be a permit. ${ }^{42}$

Furthermore, regulations related to wiretapping are contained in Title III of the Omnibus Crime Control and Safe Street Act 1968 (OCCSSA 1968). Wiretapping tapping activities develop along with the development of direct communication (oral communication) media and communication via network (wire communication) within one state (intrastate) and between states (interstate). ${ }^{43}$ Based on these conditions, the legislators emphasized the prohibition as well as the exception of wiretapping, ${ }^{44}$ prohibitions on the manufacture and use of wiretapping equipment, ${ }^{45}$ and wiretapping rules for law enforcement. ${ }^{46}$ Wiretapping is emphasized as a restricted action because it is related to protection of the right to sense of security of citizens. ${ }^{47}$ Title III OCCSSA 1968 provides wiretapping conditions, obtaining wiretapping permit, and wiretapping mechanism. Authorization for intercept is based on Section 2516 Title III OCCSSA 1968 on three conditions. First, there is a strong reason or sufficient preliminary evidence that someone is, has, or will commit a crime. Second, wiretapping is an investigator's step when another investigative step has been carried out and failed or is dangerous. Third, it is performed in certain categories of crimes, namely crimes with the threat of capital punishment, crimes related to murder, kidnapping, robbery or extortion, bribery of public officials, sports competitions, involvement in bank fraud, credit extortion, and planning of prohibited acts. It appears that wiretapping is limited to cases at the level of investigation not preliminary investigation. Likewise, the application of wiretapping steps appears to be very careful by placing wiretapping as the last step. Obtaining a wiretapping permit is regulated by submitting a written application to the Chief Justice in accordance with the jurisdiction/Federal Judge of competent jurisdiction, containing investigator identity, wiretapped person, wiretapping device to be used, wiretapping time, and reporting of wiretapping results. ${ }^{48}$ As a commitment to the protection of the right to privacy, the OCCSSA 1968 regulates Procedures for Recovery for Damages caused by wiretapping that does not comply with legal provisions (Section 2520 OCCSSA 1968).

\footnotetext{
42 United Congress, "Constitution of United States", https://constitution.congress.gov/constitution/amendment-5/, accessed on May 2020.

43 Section 801 Titel III of the OCCSSA 1968, "Omnibus Crime Control and Safe Streets Act of 1968", https://transition.fcc.gov/Bureaus/OSEC/library/legislative_histories/1615.pdf, accessed May 2020. Ibid., Section 2511 Title III. Ibid., Section 2512, 2515 Title III. Ibid., Section 2514, 2516-2519 Title III.

Title III The Omnibus Crime Control and Safe Street Act is based on the doctrine of reasonable expectations of privacy sourced from the Berger v. Katz 1967. See Reda Manthovani, Tapping vs Privacy, Jakarta: Bhuana IImu Popular, 2015, pp. 40-44.

48 OCCSSA 1968, Section 2516, 2518 (1) Title III, op.cit.
} 
Concern for the guarantee of the right to privacy has been increasingly raised after the enactment of the American Convention on Human Rights (San José Pact) on November 22, 1969. Article 11 of the San José Pact affirms the protection of the right to privacy as follows.

"1. Everyone has the right to have his honor respected and his dignity recognized.

2. No one may be the object of arbitrary or abusive interference with his private life, his family, his home, or his correspondence, or of unlawful attacks on his honor or reputation. 3. Everyone has the right to the protection of the law against such interference or attacks. ${ }^{149}$

The San José Pact affirms that the right to privacy is part of the social and political rights of citizens, which require all forms of actions that attack or interfere with their personal life, family, ownership and correspondence to be regulated by law. In line with this principle, wiretapping should not be directed as an act that violates the privacy rights of citizens (unlawful attacks).

The important thing in the regulation of wiretapping in the United States is closely related to guaranteeing the protection of the right to privacy and personal security. The OCCSSA 1968 regulates that the tapping of direct communication (oral communication) and communication via network (wire communication) can be carried out for personal or public interest. The principle of wiretapping is emphasized as an effort that does not contradict one's privacy rights or harm the interests of others. The implementation of wiretapping must also consider a person's privacy rights on the one hand, while on the other hand the interests of law enforcement. The regulation of wiretapping is also very rigid, especially in terms of wiretapping requirements, permit, and mechanism. The approval of wiretapping permit involves approval of the judicial power. This is what underlies most of the people of the United States of America's belief that the government will not abuse power even though there are still many pros and cons of securing privacy rights. ${ }^{50}$ Regarding corruption as an act that is detrimental to the state's economy, wiretapping must still be carried out according to procedures. This viewpoint is based on the consideration that the linkage of corruption to the state's economy is also closely related to the interaction with economic freedom. ${ }^{51}$

Unlike the United States, the development of wiretapping arrangements in Australia is similar to that of Indonesia. Australia views the issue of corruption as

\footnotetext{
49 General Secretary of United Nations, "American Convention on Human Rights: 'Pact of San José, Costa Rica'", https://treaties.un.org/doc/Publication/UNTS/Volume\%201144/volume-1144-I-17955-English.pdf, accessed on May 2020

50 Arwen Mulikin and Syed Shawon M. Rahman, op.cit., pp. 32-34.

51 Oguzhan Dincer, "If You're Corrupt, You'd Better Be Free", Journal of Economic Studies, Vol. 47, No. 6, 2020, p. 4.
} 
part of a national issue, ${ }^{52}$ which must be anticipated and taken seriously. The Telecommunications (Interception and Access) Act $1979^{53}$ (TIAA 1979) emphasizes the principle of prohibiting interception of communication via telecommunications (Article 7). TIAA 1979 stipulates that wiretapping is permitted with the consent of the Public Prosecutor, both for personal gain and law enforcement. In particular, for the sake of law enforcement, Article 7 paragraph (5) and (8) of the TIAA $1979^{54}$ grants an exception to a police officer (the Australian Federal Police or the Police Force of a State) in the case of a person whose communication is related to the performance of an act prohibited by law. There are three requirements for wiretapping, namely (i) an act that threatens or results in serious personal injury, (ii) suspicion of committing murder or injuring another person or causing serious damage or (iii) suspicion of committing suicide or an act of threatening life or personal health and/or others. It appears that the regulation of wiretapping is placed on the consideration of whether there is an act of attacking the life and/or health of oneself and/or others (Article 30 of the TIAA 1979). Based on the definition of Transparency International, ${ }^{55}$ corruption is an act that is detrimental to society related to the integrity of a person in a position and dangerous to damage the economy and the integrity of state. ${ }^{56}$ Therefore, wiretapping can be carried out in corruption case.

In addition to the public prosecutor, a local court judge must also approve wiretapping permit. According to the due process, the Court has the main authority to judge an act as corruption or misconduct. ${ }^{57}$ The role of court is also very important considering that corruption in Australia is not regulated in one law but sectoral laws. They are, among others, the Criminal Code Act 1995, Public Service Act 1999, International Trade Integrity Act 2007, Financial Management and Accountability Act 1997, Corporations Act 2001, Proceeds of Crime Act 2002, and other laws and regulations. ${ }^{58}$ This means that court involvement in approval of wiretapping permits is considered very important in law enforcement because it is closely related to protection of privacy rights.

Compared to wiretapping arrangements in the Second Amendment of the KPK Law, the United States and Australia have both similarities and differences.

52 Diana Bowman \& George Gilligan, "Public Awareness of Corruption in Australia", Journal of Financial Crime, Vol. 14, No. 4, 2007, pp. 438-452.

53 Australian Government, "Telecommunications (Interception and Access) Act 1979", https://www.legislation.gov.au/Details/C2017C00192, accessed on May 2020.

$54 \quad$ Ibid

55 Transparency International, "What is Corruption?", 2012, www.transparency.org/ whatwedo? GclidCMmQoarv27ECFaRMpgod_T4A0w, accessed on May 2020.

56 Paul Latimer, "Anti-Bribery Laws-Compiance Nos in Australia”, Journal of Financial Crime, Vol. 24, No. 1, 2017, p. 5.

57 Aquinas John Purcell, "Australian Local Goevernment Corruption and Misconduct", Journal of Financial Crime, Vol. 23, No. 1, 2016, p. 108.

58 Alfroza Begum, "Corruption in Business: A Critical Appraisal of the Australian Regulatory Regima in the Light of UK Bribery Act 2010", Journal of Financial Crime, p. 2, https://ro.uow.edu.au/lhapapers/4186/. 
Although they both emphasize the due process of law requirements, wiretapping is regulated differently. There are three differences: (1) the form of regulations related to wiretapping, (2) the terms and conditions for obtaining a wiretap permit, and (3) the tapping mechanism as shown in the following table.

Table 1. Comparison of Wiretapping Arrangements in the OCCSSA 1968, the TIAA 1979 and the Second Amendment of the KPK Law

\begin{tabular}{|c|c|c|c|}
\hline $\begin{array}{l}\text { Object of } \\
\text { Regulation }\end{array}$ & OCCSSA 1968 & TIAA 1979 & $\begin{array}{l}\text { Second Amendment } \\
\text { of the KPK Law }\end{array}$ \\
\hline Form of rule & Omnibus Law & Special Laws & Sectoral Laws \\
\hline Terms & $\begin{array}{l}\text { 1. Strong } \\
\text { reasons/sufficient } \\
\text { preliminary } \\
\text { evidence } \\
\text { (Investigation } \\
\text { stage); crimes } \\
\text { 2. For to the } \\
\text { subject to } \\
\text { capital } \\
\text { punishment, } \\
\text { crimes related to } \\
\text { murder, } \\
\text { kidnapping, } \\
\text { robbery } \\
\text { extortion, bribery } \\
\text { of public officials, } \\
\text { sports of } \\
\text { competitions, } \\
\text { involvement in } \\
\text { bank fraud, credit } \\
\text { extortion, } \\
\text { planning of a } \\
\text { prohibited acts. }\end{array}$ & 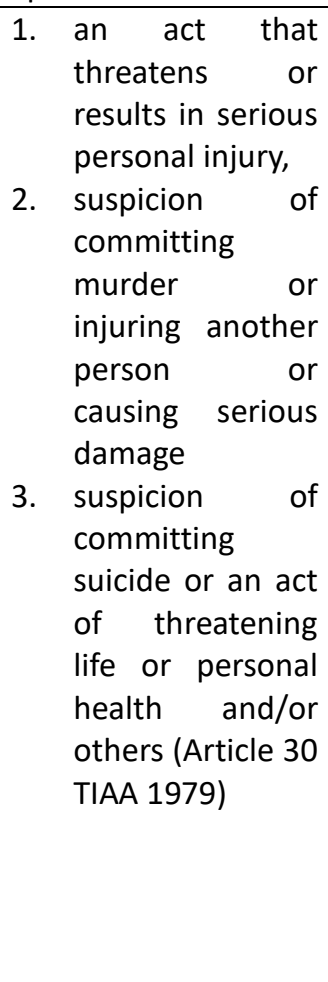 & $\begin{array}{l}\text { Conducted at the } \\
\text { stage of preliminary- } \\
\text { investigation, } \\
\text { investigation, and } \\
\text { prosecution (Article } \\
12 \text { paragraph (1) in } \\
\text { conjunction with } \\
\text { Article } 4 \text { letter e); }\end{array}$ \\
\hline $\begin{array}{l}\text { Obtaining } \\
\text { permit }\end{array}$ & $\begin{array}{l}\text { Written application } \\
\text { to the Chairman of } \\
\text { the Court in } \\
\text { accordance with } \\
\text { jurisdiction (Federal } \\
\text { Judge of competent } \\
\text { jurisdiction) -Section } \\
2516,2518 \text { (1) }\end{array}$ & $\begin{array}{l}\text { The application is } \\
\text { submitted in writing } \\
\text { to the local court } \\
\text { judge after obtaining } \\
\text { the Prosecutor's } \\
\text { approval }\end{array}$ & $\begin{array}{l}\text { 1. The wiretapping } \\
\text { approval is } \\
\text { processed in } \\
\text { stages from the } \\
\text { preliminary } \\
\text { Investigator/Inves } \\
\text { tigator to the } \\
\text { KPK, followed by } \\
\text { the title of the } \\
\text { case in front of } \\
\text { the KPK }\end{array}$ \\
\hline
\end{tabular}




\begin{tabular}{|c|c|c|c|}
\hline & & 2. & $\begin{array}{l}\text { Supervisory } \\
\text { Board; } \\
\text { Submit a written } \\
\text { application to the } \\
\text { Supervisory } \\
\text { Board. }\end{array}$ \\
\hline Mechanism & 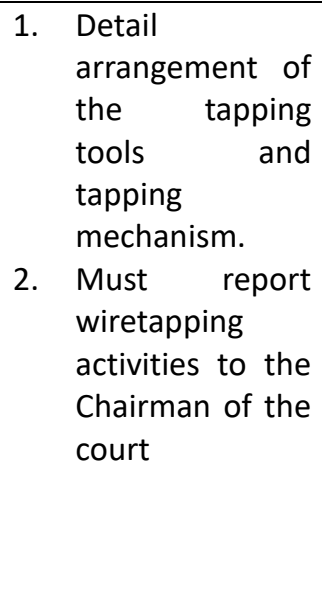 & 1. & $\begin{array}{l}\text { The tapping } \\
\text { method has not } \\
\text { been regulated } \\
\text { separately; } \\
\text { wiretapping } \\
\text { activities must be } \\
\text { reported to the } \\
\text { KPK } \\
\text { Leadership; } \\
\text { Accountability for } \\
\text { tapping results to } \\
\text { the leaders and } \\
\text { the Supervisory } \\
\text { Board of KPK. }\end{array}$ \\
\hline
\end{tabular}

Source: OCCSSA 1968, TIAA 1979, \& the Second Amendment of the KPK Law

Based on the table, the Second Amendment of the KPK Law on the one hand has advantages but on the other hand, it has disadvantages. The regulation of wiretapping in the United States is regulated in the form of an Omnibus law, while Australia regulates it in a Special Law. The choice of legal rules in the form of Omnibus law and Special Laws provides general guidelines for wiretapping operations, in contrast to the second amendment of the KPK Law, which provides sectoral regulation. This means that the wiretapping regulation is valid only to regulated crimes. As a result, the regulation or mechanism of wiretapping varies from one law to another. ${ }^{59}$

In normative juridical terms, wiretapping of corruption case can be carried out at all levels of law enforcement. The OCCSSA 1968 and TIAA 1979 limit wiretapping to be carried out on the basis of sufficient evidence (investigation stage). The OCCSSA 1968 and the TIAA 1979 both emphasize the protection of the right to security or the right to privacy as the main thing in law enforcement. This does not mean that the Second Amendment of the KPK Law does not emphasize the protection of the right to security or the right to privacy. Tapping carried out at the preliminary-investigation stage certainly does not have strong reasons or strong evidence so that it is vulnerable to violating the rights to personal security or the privacy rights of others. It is in line with the provisions of Article 28J of the 1945

59 
Constitution that restrictions on human rights can be carried out if they conflict with respect for the rights and freedoms of others and fulfill fair demands according to considerations of moral, religious values, security, and public order. Therefore, if law enforcement through wiretapping must be carried out, it can be ascertained beforehand that there is a strong suspicion or sufficient evidence of the occurrence of a criminal act of corruption. Then, tapping can be carried out and does not violate a person's human rights. Therefore, if law enforcement using wiretapping must be carried out, it can be ascertained beforehand that there is a strong suspicion or sufficient evidence of the occurrence of a criminal act of corruption. Based on the idea, wiretapping can be carried out and does not violate a person's human rights.

Another difference is in permit and mechanism. Both the 1968 OCCSSA and the 1979 TIAA confirm written permission from other agencies-Chairman of the Court, according to jurisdiction. The Second Amendment of the KPK Law actually confirms that wiretapping permit must be submitted internally to the KPK leaders and the Supervisory Board. This actually shows that there is no difference in the mechanism for filing wiretapping applications from the previous KPK Law to the second amendment. The implementation of which is internally in the KPK. The difference lies in the submission procedure from the KPK Leaders to the Supervisory Board. Tiered approval for wiretapping characterizes the due process model that prioritizes legal procedures, look for quality, and apply the presumption of innocence. Sufficient evidence is required to obtain wiretapping approval at each level, which wastes a lot of time.

\section{Conclusion}

The policy on wiretapping for corruption case in Indonesia follows the characteristics of corruption. The Corruption Eradication and Prevention Law affirm that corruption is an act that is detrimental to the state's finances and economy and is considered extraordinary crime. Wiretapping by the KPK aims to optimize the eradication of corruption. Unfortunately, it has not been implemented effectively and efficiently. The KPK's authority to wiretap regulated in Article 12 paragraph (1) of the RI KPK Law has not been followed by regulations on wiretapping permit and mechanism. The Second Amendment of the KPK Law provides three provisions. They are, among others, the nature, the permit, and the mechanism of wiretapping. The Second Amendment of the KPK Law still emphasizes the internal wiretapping permit mechanism. However, it only adds to the length of the process for obtaining permission from the KPK RI Supervisory Board. Compared to the United States' OCCSSA 1968 and the Australia's TIAA 1978, which enforces the due process of law, the wiretapping arrangements in the KPK Law is different. The OCCSSA 1968 and the TIAA 1978 emphasize the importance of guaranteeing and protecting the right to privacy through limited wiretapping requirements at the level of investigation. Permit proposal is submitted to the Chief Justice in accordance with the jurisdiction 
and it requires activity reports. The Second Amendment of the KPK Law regulates that wiretapping can be done at all stages of the legal process. Wiretapping permit and report are carried out through the KPK RI internal mechanism. Therefore, due process of law has not been fully implemented in the wiretapping of corruption cases.

\section{References}

\section{Books}

Eddy O.S. Hiariej, Hukum Pembuktian, Erlangga, Jakarta, 2012.

Garner, Bryan A., Black's Law Dictionary, Eighth Edition, West-Thomson, New York, 2004.

Packer, Herbert L., The Limits of Criminal Sanction, Standford University Press, Standford, 1968.

Reda Manthovani, Penyadapan vs Privasi, Bhuana Ilmu Populer, Jakarta, 2015.

S. Faisal, Menerobos Positivisme Hukum, Kritik terhadap Peradilan Asrori, Gramata Publishing, Bekasi, 2012.

\section{Other Documents}

Anderson, Beverlee B., "Corrupting Activities and Economic Development", World Journal of Entrepreneurship, Management and Sustainable Development, Vol. 11, No. 1, 2015.

Armunanto Hutahean and Erlyn Indarti, "Implementation of Investigation by the Indonesian National Police in Eradicating Corruption Crime", Journal of Money Laundering Control, Vol. 23, No. 1, 2020.

Begum, Alfroza., "Corruption in Business: A Critical Appraisal of the Australian Regulatory Regima in the Light of UK Bribery Act 2010", Journal of Financial Crime, https://ro.uow.edu.au/lhapapers/4186/.

Bernardi, R.A., \& Hayashi, I., "The Association Between Bribery and Unethical Actions: An Asian Perspective", European Journal of Business and Innovation Research, Vol. 1, No. 2, 2013.

Bowman, Diana., \& Gilligan, George., "Public Awareness of Corruption in Australia", Journal of Financial Crime, Vol. 14, No. 4, 2007.

Dincer, Oguzhan., "If You're Corrupt, You'd Better Be Free", Journal of Economic Studies, Vol. 47, No. 6, 2020.

Dion, Michel., "What is Corruption Corrupting? A Philosophical Viewpoint", Journal of Money Laundering Control, Vol. 13, No. 1, 2010.

Dworkin, Roger B., "The Limits of the Criminal Sanction, by Herbert L. Packer", Indiana Law Journal, Vol. 44, No. 3, 1969.

Edkins, Vanessa A., \& Royal, Kenneth D., "Evaluating the Due Process and Crime Control Perspectives Using Rasch Measurement Analysis", Journal of Multidisciplinary Evaluation, Vol. 7, No. 16, 2011. 
Edmon Makarim, "Indonesia: the Controversy Over the Bill Concernining Lawful Interception", Digital Evidence and Electronic Signature Law Review, Vol. 8, No. $1,2011$.

Endah Lismartini \& Cahyo Edi, ed., "Busyro: Izin Penyadapan Masuk dalam Upaya Pelemahaman KPK", https://www.vivanews.com/berita/nasional/5821-busyroizin-penyadapan-masuk-dalam-upaya-pelemahan-kpk?medium=autonext.

Gottschalk, Petter., "Categories of Finansial Crime", Journal of Financial Crime, Vol. 17, No. 4, 2010.

Hendi Yogi Prabowo \& Cooper, K., "Re-understanding Corruption in the Indonesian Public Sector Through Three Behavioral Lenses", Journal of Financial Crime, Vol. 23, No. 4, 2016.

Hwian Christianto, "Tindakan Penyadapan Ditinjau dari Perspektif Hukum Pidana", Jurnal Hukum Prioris, Vol. 5, No. 2, 2016.

Hwian Christianto, "Penyadapan, OTT dan Due Process of Law", https://www.jawapos.com/opini/18/10/2019/penyadapan-ott-dan-due-processof-law/.

Kaylor, Elizabeth H., "Crime Control, Due Process, \& Evidentiary Exclusion: When Exceptions Becoma the Rule", Proceeding of the 71st New York State Communication Association, Vol. 2013, No. 2013, New York, United States, 2014.

Kim, Yooung Jong., \& Kim, Eun Sil., "Exploring the Interrelationship Between Public Service Motivation and Corruption Theories", Evidence-Based HRM, Vol. 4, No. 2, 2016.

Latimer, Paul., "Anti-Bribery Laws-Compiance Nos in Australia”, Journal of Financial Crime, Vol. 24, No. 1, 2017.

Monteverde, Vicente H., "Microeconomics of Corruption Based on Behavioural Economics", Journal of Financial Crime, https://www.emerald.com/insight/content/doi/10.1108/JFC-03-20200043/full/html?skipTracking=true.

Mulikin, Arwen., \& Rahman, Shawon S.M., "The Ethical Dilemma of the USA Government Wiretapping", International Journal of Managing Information Technology (IJMIT), Vol. 2, No. 4, 2010.

Olken, B.A., "Corruption Perceptions vs. Corruption Reality", Journal of Public Economics, Vol. 93, No. 7, 2009.

Purcell, Aquinas John., "Australian Local Government Corruption and Misconduct", Journal of Financial Crime, Vol. 23, No. 1, 2016.

Rus, Jure., "Effective Detection and Investigation of Corruption", Proceeding Expert Seminar Effective Means of Investigation and Prosecution of Corruption: OECD Anti-Corruption Network for Eastern Europe and Central Asia, BucharestRomania, 20-22 October 2010. 
Spence, Edward Howlett., "The Sixth Estate: Tech Media Corruption in the Age of Information", Journal of Information, Communication and Ethics in Society, Vol. 18, No. 4, 2020.

Tim Penyusun Laporan Tahunan KPK 2016, "Hingga ke Bawah Permukaan: Laporan Tahun 2016 Komisi Pemberantasan Tindak Pidana Korupsi Republik Indonesia", https://www.kpk.go.id/images/Laporan\%20Tahunan\%20KPK\%202016\%20Bahas a\%20Indonesia.pdf.

Transparency International, "What is Corruption?", www.transparency.org/ whatwedo?gclidCMmQoarv27ECFaRMpgod_T4A0w.

Transparency International, "Corruption Perceptions Index", https://www.transparency.org/cpi2019.

\section{Legal Documents}

The 1945 Constitution of the Republic of Indonesia [Undang-Undang Dasar Negara Republik Indonesia Tahun 1945].

The Decision of the Constitutional Court of the Republic of Indonesia Number 5/PUU-VIII/2010 concerning Requests for Judicial Review of Article 31 paragraph (2) of the Law on Information and Electronic Transactions that Determines the Procedure for Wiretapping is Further Regulated Through Government Regulations [Putusan Mahkamah Konstitusi Republik Indonesia Nomor 5/PUUVIII/2010 tentang Permohonan Uji Materiil atas Pasal 31 ayat (2) UndangUndang Informasi dan Transaksi Elektronik yang Menentukan Tata Cara Penyadapan Diatur Lebih Lanjut Melalui Peraturan Pemerintah].

Law Number 8 of 1981 on Criminal Procedure Law [Undang-Undang Nomor 8 Tahun 1981 tentang Hukum Acara Pidana].

Law Number 5 of 1997 on Psychotropics [Undang-Undang Nomor 5 Tahun 1997 tentang Psikotropika].

Law Number 31 of 1999 on Eradication of Corruption Crime [Undang-Undang Nomor 31 Tahun 1999 tentang Pemberantasan Tindak Pidana Korupsi].

Law Number 20 of 2001 on the Amendments to the Law Number 31 of 1999 [Undang-Undang Nomor 20 Tahun 2001 tentang Perubahan Undang-undang Nomor 31 Tahun 1999].

Law Number 17 of 2004 on the People's Consultative Assembly, the People's Representative Council, the Regional Representative Council, and the Regional People's Representative Council [Undang-Undang Nomor 17 Tahun 2004 tentang Majelis Permusyawaratan Rakyat, Dewan Perwakilan Rakyat, Dewan Perwakilan Daerah dan Dewan Perwakilan Rakyat Daerah].

Law Number 35 of 2009 on Narcotics [Undang-Undang Nomor 35 Tahun 2009 tentang Narkotika].

Law Number 19 of 2019 on the Second Amendment to the Law Number 30 of 2002 on the Corruption Eradication Commission [Undang-Undang Nomor 19 Tahun 
2019 tentang Perubahan Kedua Undang-Undang Nomor 30 Tahun 2002 tentang Komisi Pemberantasan Tindak Pidana Korupsi].

Omnibus Crime Control and Safe Streets Act of 1968.

OYEZ, Olmstead v. United States, Case 277 US 438, 1928.

OYEZ, Katz v. United States, Case 389 US 347, 1967.

American Convention on Human Rights Pact of San José, Costa Rica.

Australian Government, Telecommunications Interception and Access Act 1979.

United Nations Office on Drugs and Crime, National Strategy Corruption Prevention and Eradication of Republic of Indonesia.

United States Congress, Constitution of United States. 